\title{
Fenugreek (Trigonella foenum-graecum) induced interstitial nephritis
}

\author{
Sepideh Zununi-Vahed ${ }^{1}$, Mohammadreza Ardalan ${ }^{1 *}$, Fariba Mahmoodpoor ${ }^{1}$, Kasra Ardalan $^{2_{9}}$ Ramin \\ Tolouian $^{3}$ \\ ${ }^{1}$ Kidney Research Center, Tabriz University of Medical Sciences, Tabriz, Iran \\ ${ }^{2}$ Faculty of Pharmacy, Eastern Mediterranean University, Famagusta, Turkish Republic of North Cyprus \\ ${ }^{3}$ Division of Nephrology and Hypertension, University of Central Florida, college of medicine, Orlando, FL, USA
}

\section{A R T I C L E IN F O}

Article Type:

Case Report

\section{Article History:}

Received: 10 May 2017

Accepted: 16 July 2017

Published online: 4 August 2017

Keywords:

Herbal

Fenugreek

Interstitial nephritis

Hemolytic anemia

Acute interstitial nephritis

\begin{abstract}
A B S T R A C T
Herbal medicine has grabbed the public interest and there is a general belief of their safety and life compatibility. There are growing proportion of reported side effects of herbal medicine in past years. We reported a 62-year-old woman who developed acute interstitial nephritis (AIN) accompanied by autoimmune hemolytic anemia (AIHA), three weeks after daily ingestion of heat extract of fenugreek. The patient's renal, hematologic and liver panels were improved after steroid pulse therapy and fenugreek discontinuation. Fenugreek contains high amount of flavonoid which might be a main culprit for AIN and AIHA.
\end{abstract}

Implication for health policy/practice/research/medical education:

Fenugreek (Trigonella foenum-graecum) contains high amount of flavonoid which might be a main culprit for AIN and AIHA. Please cite this paper as: Zununi-Vahed S, Ardalan MR, Mahmoodpoor FM, Ardalan K, Tolouian R. Fenugreek (Trigonella foenum-graecum) induced interstitial nephritis. J Renal Inj Prev. 2017;6(4):286-288. DOI: 10.15171/jrip.2017.54.

\section{Introduction}

Herbal medicine has gained much popularity in recent years and there is a general belief of safety toward them. The side effects and adverse reactions of those agents are not well described or studied. Many herbs are not what they claim to be and often contain ingredients not listed on the label. Herbal medications consumption may be dangerous and cause problems in different organs by different mechanisms (1).

Star fruit (Averrhoa carambola L.) are known to create oxalate nephrotoxicity, Thunder God Vine (Tripterygium wilfordii Hook) and some traditional African medicines such as Securida longipedunculata, Euphoria matabelensis, Callilepis laureola (Cape aloes) are potent renal tubular toxins. Cranberry juice and Roughbark (Guaicum officinale L.) increase the risk of kidney stones. Ephedra sinica Stapf and Devil's Claw (Harpagophytum procumbens
DC. Ex Meisn.) contain ephedrine and can raise the blood pressure dramatically (1-3).

Tribulus terrestris that is considered as a lithotripsic and renal protective herb has been reported as a nephrotoxic (4). Acute allergic interstitial nephritis has been reported after the intake of Peruvian Cat's claw (Uncaria tomentosa) (5). Aristolochic acid from Aristolochia species is the responsible agent for chronic interstitial nephritis, Balkan nephropathy and urothelial carcinoma (5). Herbal poisoning may be due to their heavy metals or microbial or fungal toxin contamination. It is possible that herbal therapy may be an underreported cause of end-stage renal disease (ESRD) in different regions worldwide (6-8).

\section{Case Presentation}

A 62-year-old woman with no significant past medical history except type II diabetes mellitus under the treatment 
of metformin, which was in her usual state of health till one week prior to her admission to the hospital. Initially, her symptoms started with general weakness. Fatigue and shortness of breath were her chief complaints. After admission in a local hospital renal failure was detected. They assumed the renal failure would be an acute process, while she has not any previous history of kidney disease. Despite parenteral fluid and supportive therapy, her general condition deteriorated. Patient then transferred to our hospital when she became oliguric. On admission, she was alert and oriented. However, she was irritable. Blood pressure (BP) was $119 / 79 \mathrm{~mm} \mathrm{Hg}$, pulse rate $106 / \mathrm{min}$, respiratory rate $26 / \mathrm{min}$ and her temperature was $38^{\circ} \mathrm{C}$. Physical examination revealed icteric sclera with pale conjunctiva. A cardiac examination showed tachycardia with no murmur. Her lungs had inspiratory crackles over both basal lung fields. No organomegaly, skin rashes or lower leg edema detected.

Laboratory data showed the following values; white blood cells of $8000 / \mu \mathrm{L}$. Plasma hemoglobin $=8.6 \mathrm{~g} / \mathrm{dL}$, platelets counts $=104000 / \mu \mathrm{L}$, serum creatinine $=4.3 \mathrm{mg} / \mathrm{dL}$, blood urea nitrogen $=51 \mathrm{mg} / \mathrm{dL}$, aspartate aminotransferase $(\mathrm{AST})=79 \mathrm{IU} / \mathrm{L}(0-40)$, alanine aminotransferase (ALT) = $63 \mathrm{IU} / \mathrm{L}(0-40)$ and blood glucose was $185 \mathrm{mg} / \mathrm{dL}$. Accordingly serum electrolytes $\mathrm{Na}=138 \mathrm{mEq} / \mathrm{L}$ and serum $\mathrm{K}$ was $4.8 \mathrm{mEq} / \mathrm{L}$. Urine analysis showed; $2+$ protein $2+$ blood with 2 to 5 red blood cells, and 5-10 leukocytes high power field. Total bilirubin level was $6.7 \mathrm{mg} / \mathrm{dL}$ with direct bilirubin of $2.1 \mathrm{mg} / \mathrm{dl}$, serum alkaline phosphatase level was 183 IU/L (normal, 32 to 92 IU/L). Additionally serologic study for $\mathrm{HBV}, \mathrm{HCV}$, and HIV were negative. An arterial blood gas analysis showed a $\mathrm{pH}$ of 7.30 with bicarbonate of $14.4 \mathrm{mmol} / \mathrm{L}$. A lactate dehydrogenase level of $1920 \mathrm{IU} / \mathrm{L}$, with a creatine kinase (CPK) level of $237 \mathrm{U} / \mathrm{L}$ was found. Finally prothrombin time and active partial thrombin time were normal.

She was admitted with the presumed diagnosis of hemolytic-uremic syndrome. Further work up showed positive indirect antiglobulin (indirect coombs) test. No schistocyte was noted in her peripheral blood smear. The antinuclear antibody (ANA) was negative. The patient underwent renal biopsy and was placed on intravenous methylprednisolone (500 $\mathrm{mg} /$ daily) for three consecutive days. Subsequently, her urine output, general condition, renal, liver and anemia panels started to improve. Her serum creatinine decreased from 4.3 to $1.7 \mathrm{mg} / \mathrm{dL}$ two weeks after biopsy. A light microscopic study of kidney biopsy revealed renal interstitial edema and infiltration with mononuclear cells and eosinophils that was suggestive of allergic acute interstitial nephritis (AIN) (Figure 1). Immunofluorescent studies showed no immune deposits.

\section{Discussion}

We reported a diabetic woman who presented with the clinical picture of hemolytic-uremic syndrome. This patient had no history of diarrhea or febrile disease as a trigger for classic hemolytic uremic syndrome (HUS). Lack of thrombocytopenia and schistocyte in peripheral

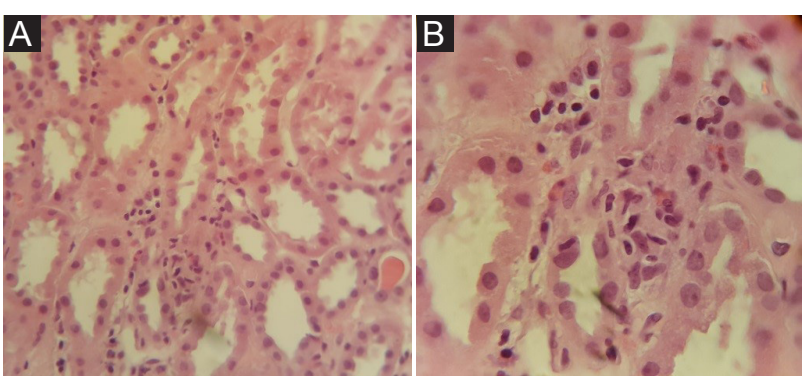

Figure 1. (A) Light microscopy of renal biopsy $\times 40(\mathrm{H \& E})$, mononuclear cell infiltration is prominent in the center of the slide. (B) Light microscopy of renal biopsy $\times 100(\mathrm{H} \& \mathrm{E})$, mononuclear cell infiltration around the tubules are prominent. The cells with purple cytoplasm and two nuclei (sunglass-like cells) are eosinophils.

blood smear made thrombotic thrombocytopenic purpura (TTP) unlikely. Finally, negative direct coombs test and no evidence of thrombotic microangiopathic changes in renal biopsy were against presence of atypical or complement mediated HUS (9). The renal biopsy was consistent with AIN which is a relatively uncommon diagnosis in nephrology practice. The exposure to drugs is the main cause of AIN in almost $75 \%$ of cases. Systemic disease and infection are other common etiologies for this problem (10).

This patient had no clinical feature in favor of any infection or systemic disease. She also had no changes in her medication list except including to take over-the-counter heat extract fenugreek three weeks prior her admission having a better blood sugar control. Fenugreek is used as an herb, spice and vegetable in cooking for centuries. It has been proposed as a glucose modulating treatment in patients with diabetes mellitus (11). Clinical presentations of drug induced AIN are often similar. Patients may present with proteinuria, hematuria, fever, rash, flank pain, oliguria, arthralgia, eosinophilia and a sudden onset of worsening of renal function. The renal failure is the only constant clinical manifestation in AIN and usually manifest within three weeks of starting offending agent. The renal replacement therapy may be necessary in half of patients with renal failure (12).

Renal biopsy still is an essential tool to confirm the diagnosis of AIN as eosinophiluria is a low sensitive test $(13,14)$. Patchy infiltration of mononuclear cells, predominantly eosinophil around the tubules with normal glomeruli and vessels were more in favor of allergic AIN in this case.

In the literature reviews, we found nine reported cases of flavonoid-induced nephropathy who presented with AIN accompanied by autoimmune hemolytic anemia (AIHA) very similar to our case. The mechanism of flavonoid nephropathy is unknown however, an immune-mediated mechanism is highly possible $(15,16)$. Flavonoids are found ubiquitously in many herbs, including fenugreek and their antioxidant activities and its cytoprotective effect has frequently been praised in different studies $(17,18)$. We speculated that exposure to high flavonoid content 
of fenugreek dried extract might be a culprit for AIN and hemolytic anemia in our patient. The most important step in treating AIN is removing the offending agent. Our patient received three days high dose steroid. The role of steroid in AIN is debatable but we have observed dramatic response in this patient's renal function, urine output and overall wellbeing. The lack of interstitial fibrosis, patchy infiltrates without granuloma formation in addition to decreasing creatinine to $1.4 \mathrm{mg} / \mathrm{dL}$ in two weeks lends itself toward a good renal prognosis.

This is the first report of fenugreek induced allergic AIN accompanied by AIHA.

It may prove wise to question each patient who presenting with acute renal dysfunction of unknown origin about using of herbal/over-the-counter medications. Timely recognition and discontinuation of the offending agent appears to provide the utmost therapeutic role at this time.

\section{Authors' contribution}

MRA handled the patient. KA prepared the primary draft. MRA conducted final edition. All authors read and signed the final manuscript.

\section{Conflicts of interest}

The authors declare that they have no competing interests.

Ethical considerations

Ethical issues (including plagiarism, data fabrication, double publication) have been completely observed by the authors. Informed consent was obtained from the patient for publication as a case report.

\section{Funding/Support}

None.

\section{References}

1. Luyckx VA, Ballantine R, Claeys M, Cuyckens F, Van den Heuvel H, Cimanga RK, et al. Herbal remedyassociated acute renal failure secondary to Cape aloes. Am J Kidney Dis. 2002;39:E13.

2. Adelekun TA, Ekwere TR, Akinsola A. The pattern of acute toxic nephropathy in Iife, Nigeria. West Afr J Med.1999;18:60-3.

3. Diamond J, Pallone T. Acute interstitial nephritis following use of tung shueh pills. Am J Kidney Dis. 1994;24:219-21.

4. Allard T, Wenner T, Greten HJ, Efferth T. Mechanisms of herb-induced nephrotoxicity. Curr Med Chem.
2013;20:2812-9.

5. Ardalan MR, Khodaie L, Nasri H, Jouyban A. Herbs and hazards: risk of aristolochic acid nephropathy in Iran. Iran J Kidney Dis. 2015;9:14-7.

6. Ardalan MR, Samadifar Z, Vahedi A. Creatine monohydrate supplement induced interstitial nephritis. J Nephropathol. 2012;1:117-20. doi: $10.5812 /$ nephropathol.7530.

7. Nortier JL, Vanherweghem JL. Renal interstitial fibrosis and urothelial carcinoma associated with the use of a Chinese herb (Aristolochia fangchi). Toxicology. 2002;181:577-80.

8. Guh JY, Chen HC, Tsai JF, Chuang LY. Herbal therapy is associated with the risk of CKD in adults not using analgesics in Taiwan. Am J Kidney Dis. 2007;49:62633.

9. Ardalan MR. Review of thrombotic microangiopathy (TMA), and post-renal transplant TMA. Saudi J Kidney Dis Transpl. 2006;17:235-44.

10. Muriithi AK, Leung N, Valeri AM, Cornell LD, Sethi S, Fidler ME, et al. Biopsy-proven acute interstitial nephritis, 1993-2011: a case series. Am J Kidney Dis. 2014;64:558-66. doi: 10.1053/j.ajkd.2014.04.027.

11. Gaddam A, Galla C, Thummisetti S, Marikanty RK, Palanisamy UD, Rao PV. Role of Fenugreek in the prevention of type 2 diabetes mellitus in prediabetes. J Diabetes Metab Disord. 2015;14:74.

12. Rossert J. Drug-induced acute interstitial nephritis. Kidney Int. 2001;60:804-17.

13. Fletcher A. Eosinophiluria in acute interstitial nephritis. N Engl J Med. 2008;358:1760-1.

14. Muriithi AK, Nasr SH, Leung N. Utility of urine eosinophils in the diagnosis of acute interstitial nephritis. Clin J Am Soc Nephrol. 2013;8:1857-62. doi: $\quad 10.2215 /$ CJN.01330213.

15. Lin JL, Ho YS. Flavonoid-induced acute nephropathy. Am J Kidney Dis. 1994;23:433-40.

16. Lee JJ, Chen HC. Flavonoid-induced acute nephropathy by Cupressus funebris Endl (Mourning Cypress). Am J Kidney Dis. 2006;48:e81-5.

17. Ohkita M, Nakajima A, Ueda K, Takaoka M, Kiso Y, Matsumura Y. Preventive effect of flavangenol on ischemia/reperfusion-induced acute renal failure in rats. Biol Pharm Bull. 2005;28:1655-7.

18. Kaviarasan S, Ramamurty N, Gunasekaran P, Varalakshmi E, Anuradha CV. Fenugreek (Trigonella foenum graecum) seed extract prevents ethanolinduced toxicity and apoptosis in Chang liver cells. Alcohol Alcohol. 2006;41:267-7

Copyright (C) 2017 The Author(s); Published by Nickan Research Institute. This is an open-access article distributed under the terms of the Creative Commons Attribution License (http://creativecommons.org/licenses/by/4.0), which permits unrestricted use, distribution, and reproduction in any medium, provided the original work is properly cited. 